\section{YEARS \\ Cerebrovascular \\ Diseases}

\title{
Young Investigator Awards at the European Stroke Conference 2010
}

Fifteen young investigators received awards for excellent contributions to the European Stroke Conference in Barcelona. Members of the Scientific and the Programme Committees reviewed all abstracts submitted by investigators younger than 35 years that gained the highest rankings for originality, importance, methodological expertise, efforts needed and quality of presentation. Two groups were distinguished (table 1): (i) contributions from authors involved in large trial or registry analysis and (ii) contributions from authors who designed, conducted and analysed individual studies.

Michael G. Hennerici

Table 1. Young/junior investigators

\begin{tabular}{|c|c|c|c|}
\hline Ranking & Name & Country & Study \\
\hline \multicolumn{4}{|c|}{ (i) Studies using data from other people - clinical trials } \\
\hline 1 & C.B. Josephson & UK & SAIVMs - The Scottish Audit of Intracranial Vascular Malformations \\
\hline 2 & H. Tu & Australia & VISTA - The Virtual International Stroke Trials Archive \\
\hline 3 & A.G.W. van Norden & The Netherlands & The RUN DMC Study \\
\hline 4 & D.A. Doig & UK & ICSS - The International Carotid Stenting Study \\
\hline 5 & O.C. Sheehan & Ireland & NDPSS - The North Dublin Population Stroke Study \\
\hline 6 & S. Wiedmann & Germany & EROS - The European Registries of Stroke Collaboration \\
\hline 7 & C. Guidoux & France & MASSS - Prevalence and role of amyloid angiopathy in cerebral haemorrhage \\
\hline \multicolumn{4}{|c|}{ (ii) Original studies with own data - investigator diverse studies } \\
\hline 1 & M. Rubiera & Spain & $\begin{array}{l}\text { Bridging IV-IA rescue increases recanalization and likelihood of good outcome in non-responder IV } \\
\text { tPA-treated patients - a case-control study }\end{array}$ \\
\hline 2 & C.D. d'Esterre & Israel & $\begin{array}{l}\text { Effect of dipyridamole on cerebral circulation and stroke outcome in a rabbit model of middle cerebral } \\
\text { artery embolic occlusion }\end{array}$ \\
\hline 3 & B. Lapergue & France & Protective effect of high-density lipoprotein-based therapy in a model of embolic stroke \\
\hline 4 & B. Hotter & Germany & ABCD2 score predicts cerebral infarction on DWI \\
\hline 5 & J. Minnerup & Germany & Methodological quality of animal experimental stroke studies does not predict high impact publishing \\
\hline 6 & F. Pescini & Italy & $\begin{array}{l}\text { Biological and instrumental markers of endothelial dysfunction in CADASIL (Cerebral Autosomal } \\
\text { Dominant Arteriopathy with Subcortical Infarcts and Leukoencephalopathy) }\end{array}$ \\
\hline 7 & F. Campos & Spain & New therapies for brain ischemia based on blood glutamate scavengers \\
\hline 8 & F.N. Albach & Germany & Stroke recurrence on MRI within the first seven days after ischemic stroke \\
\hline
\end{tabular}

\section{KARGER}

Fax +41613061234 E-Mail karger@karger.ch www.karger.com
(C) 2010 S. Karger AG, Basel

$1015-9770 / 10 / 0304-0345 \$ 26.00 / 0$

www.karger.com/ced 